\title{
CAMBRIDGE
}

\section{Geomorphology in the Anthropocene}

\section{Andrew S. Goudie and Heather A. Viles}

4 Among contemporary physical geographers, there are none who are the equal of Andrew Goudie and Heather Viles in their ability to synthesize vast areas of the literature and to bring out new meanings from the avalanche of data that is published each week ... This is the first book that explores, in depth, the relation between the Anthropocene epoch and landscape science (geomorphology) ... [It] can be recommended to any serious student of the global implications of human modification of Earth's surface ... [as well as to the] geoscience and environmental science communities, from geographers to geologists and geophysicists. 7

Olav Slaymaker, University of British Columbia

4 What an interesting topic! What a good book! It presents the geomorphological evidence for the concept of the Anthropocene ... Breathtaking in scope, it also gives a fine account of geomorphological processes and landforms linked to human achievements. 7

Denys Brunsden, King's College London

4 In this comprehensive examination of human impacts on diverse landscapes, Goudie and Viles provide numerous examples and details of how human

\section{Geomorphology} in the Anthropocene

Andrew S. Goudie and Heather Viles

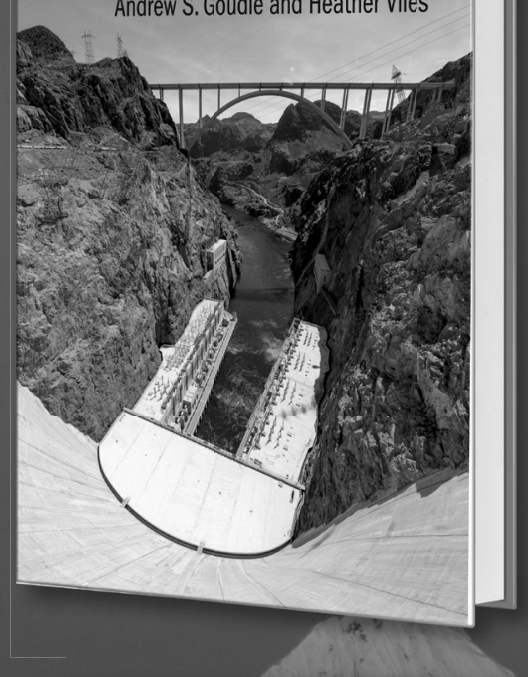

September 2016 | Hardback 380pp | 99 illus. | 9781107139961

£39.99 / \$74.99 activities have altered and continue to alter Earth's surface. 7

Ellen Wohl, colorado State University

4 In today's climate of media-induced alarm about what mankind is doing to our planet, this book stands out as a calm and considered appraisal of human impacts on Earth resources and natural systems. 7

Michael Crozier, Victoria University of Wellington

- The Anthropocene has become a hot topic in the last decade or so and the relationship between geomorphology and the Anthropocene needs to be explored

- Provides a new focus for the field of geomorphology, helping to stimulate further research paths

- Links geomorphology to major environmental issues and human concerns, such as future climate change, illustrating the value of this discipline

Covering all major aspects of geomorphology, this book is ideal for undergraduate and graduate students studying geomorphology, environmental science and physical geography, and for all researchers of geomorphology.

Visit: www.cambridge.org/goudie-viles 
PUBLISHED BY THE PRESS SYNDICATE OF THE UNIVERSITY OF CAMBRIDGE The Pitt Building, Trumpington Street, Cambridge CB2 1RP, United Kingdom

CAMBRIDGE UNIVERSITY PRESS

Journals Fulfillment Department, UPH, Shaftesbury Road,

Cambridge, CB2 8BS, UK, United Kingdom

One Liberty Plaza, New York, NY 10006, USA

477 Williamstown Road, Port Melbourne, VIC 3207, Australia

Ruiz de Alarcón 13, 28014 Madrid, Spain

Dock House, The Waterfront, Cape Town 8001, South Africa 


\section{GEOLOGICAL MAGAZINE}

\section{CONTENTS}

\section{ORIGINAL ARTICLES}

Cone-in-cone and beef mineralization associated with Triassic growth basin faulting and shallow shale diagenesis, Edgeøya, Svalbard

Maher, H. D., Ogata, K. \& Braathen, A.

Emplacement age and isotopic composition of the Prairie Lake carbonatite complex, Northwestern Ontario, Canada

Wu, F.-Y., Mitchell, R. H., Li, Q.-L., Zhang, C.

\& Yang, $\mathrm{Y} . \mathrm{-H}$.

Cenomanian-Turonian marine amniote remains from the Saxonian Cretaceous Basin of Germany

Sachs, S., Wilmsen, M., Knüppe, J., Hornung, J. J.

\& Kear, B. P.

Lower Wenlock black shales in the northern Holy Cross Mountains, Poland: sedimentary and geochemical controls on the Ireviken Event in a deep marine setting Smolarek, J., Trela, W., Bond, D. P. G. \& Marynowski, L.

The Liuyuan Volcanic Belt in NW China revisited: evidence for Permian rifting associated with the assembly of continental blocks in the Central Asian Orogenic Belt Wang, Y., Luo, Z., Santosh, M., Wang, S. \& Wang, N.

The origin of the c. 1.7 Ga gabbroic intrusion in the Hekou area, SW China: constraints from SIMS U-Pb zircon geochronology and elemental and $\mathrm{Nd}$ isotopic geochemistry

Zhu, W.-G., Bai, Z.-J., Zhong, H., Ye, X.-T. \& Fan, H.-P.
Lithostratigraphy and biostratigraphy of the Lower Carboniferous (Mississippian) carbonates of the southern Askrigg Block, North Yorkshire, UK Waters, C. N., Cózar, P., Somerville, I. D., Haslam, R. B., Millward, D. \& Woods, M.

Integrated conodont biostratigraphy and carbon isotope chemostratigraphy in the Lower-Middle Ordovician of southern Sweden reveals a complete record of the MDICE

Wu, R., Calner, M. \& Lehnert, O.

Rapid extensional unroofing of a granite-migmatite dome with relics of high-pressure rocks, the Podolsko complex, Bohemian Massif

Žák, J., Sláma, J. \& Burjak, M.

\section{RAPID COMMUNICATIONS}

Foreland-directed gravitational collapse along curved thrust fronts: insights from a minor thrust-related shear zone in the Umbria-Marche belt, central-northern Italy Pace, P., Pasqui, V., Tavarnelli, E. \& Calamita, F.

Skin impressions of the last European dinosaurs Fondevilla, V., Vila, B., Oms, O. \& Galobart, À.

\section{BOOK REVIEWS FREELY AVAILABLE ONLINE CONTENT ONLY}

